\title{
Tractate on Critical Theory and Praxis: Implications for Professionalizing Music Education
}

\author{
Thomas A. Regelski
}

The Tractate was written following the first meeting of leading music education scholars in Buffalo. It was not, however intended as a scholarly essay. Rather, it was a declaration of assorted, numerous issues the next few meetings of founding MayDay Group members could engage with in organizing efforts at creating an organization predicated on critical communication about changing the status quo of the time. It is thus a historical document that, at the time of its writing, was an unpolished voice of one young (50ish) thinker. It has since slept largely unremarked in the MayDay Group website pages until noticed by Vince Bates. Its references to Critical Theory were posed as bases for the MayDay Group's critical agenda. Some readers might detect its spirit in the subsequent MDG ethos of "action for change," with "action" translated as "praxis." Others might prefer to note a straying from the path implored by this document. Leaders attending to the present and future directions of the Group might take new resolve from it. The document was written with a critique in mind of mid-1990s music education. Sadly, much remains to be done. Perhaps a new foundational document (or several) for the next 30 years is in order to help organize future MayDay efforts of "action for change." Until its recent reemergence I hadn't known how much the Tractate foretold of my forthcoming new book on curriculum philosophy and theory, which takes up foundational issues first raised in this Tractate. I hope its current and future relevance are clear, even when it wanders more than a little.

\section{PART I}

\section{Introduction}

Critical Theory is not just any philosophical critique. It is a prominent and wellgrounded theoretical approach that stems from the "Frankfurt School" (Institute for Social Research at the Goethe University Frankfurt Germany) of social and political thinkers, philosophers, art critics, and psychologists early in this century in Germany. To thus distinguish Critical Theory from other species of critical social 
theory and from "critical thinking" in general, it will be referred to herein as a proper noun. Theorists such as Max Horkeiner, Walter Benjamin, Otto Kirchheimer, Friedrick Pollock, Leo Lowenthal and, more famously, Theodor W. Adorno, Herbert Marcuse, Eric Fromm, and Jurgen Habermas are all considered to be members. Critical Theory has been a major inspiration for the agenda of the MayDay group because it offers considerable practical implications for the theorizing of musicians and music educators.

The following is an informal introduction to Critical Theory. Because it was originally intended for web site readers, most sources and notes have been intentionally excluded and examples and parenthetical comments have been included in the body of the text. Formatting is also kept basic. One convention will be the use of double quotes around words, expressions and ideas that function almost as code words for certain taken for granted kinds of received knowledge. The use of single quotes is reserved, then, for coined words, or for attaching the sense of "socalled" to the expression in question. The essay provides in particular a theoretical background to help clarify and place in a larger context the ideals stated in the agenda of the MayDay Group. However, it represents only the views of its author, one of the co-founders of the MayDay initiative, and admits of the possibility that other members may well have other premises behind their support of the MayDay agenda. Examples included to clarify certain points are naturally drawn from the author's personal experience which is mainly in the United States; members from other countries will no doubt be able to furnish instances that are more applicable to their nations or regions.

In order to unify this rationale, several key themes are traced through extensively changing contexts of relevance and importance for the professional conduct of music education-in public schools and higher education, as well. It needs to be mentioned that any "critical" theory will be critical of any number of cherished paradigms. The criticism presented in this essay, however, needs to be understood as a critique in the positive and constructive sense encountered, for example, in good one-on-one musical instruction, rather than as negative and destructive in nature or purpose. Various technical terms are defined in context. It will be useful to take note of them when they are introduced because they will be used later on without further elaboration.

Regelski, Thomas A. 2020. Tractate on critical theory and praxis: Implications for professionalizing music education. Action, Criticism, and Theory for Music Education 19 (1): 6-53. https://doi.org/ 10.22176/act19.1.6 
The essay is organized into two parts with sections as follows, plus a brief summary and conclusion:

1. Traditional Theory: Scientific Positivism and Technicist Rationalism. This section outlines the inherent problems created by the empiricism and rationalism of the Enlightenment-an important example being claims made for a "what works" technology of teaching.

2. Critical Theory. This section provides the basic "critique" of the traditional theory outlined in the first section. It analyzes the problems of an uncritical acceptance of received knowledge, and of claims to absolute truth and objectivity. Instead, it points out the need for "critical educators"-teachers (including university professors) to possess critical consciousness and use critical knowledge.

3. Origins and Problems of Uncritical Subjectivity. Though the life-world is situated and subjective in important particulars, uncritical subjectivity is shown to be an unsuccessful antidote for unwarranted objectivity, particularly in connection with an almost religious but unwarranted belief in so-called "good methods" and the resulting but false assumption that such methods guarantee "good results." A distinction is made between "what works" misunderstood as mere practicability of methods, and the need to judge "what works" against standards provided by a warranted and functionally designed curriculum.

4. Curriculum: Ideology versus a Phronesis of "Good Results." Negative aspects of various ideological influences-both from outside and from within music education-are presented. The need for "ideology critique" on the part of teachers is argued and a curricular theory of teaching as praxis is developed in terms of an ethical criterion of promoting "good results" for students as a result of their musical schooling. "Good methods," in this argument, are seen only in connection with "good results" qualified in terms of "action ideals" by a curriculum that promotes personal musical agency.

5. Critical Theory, Research Theory and Teaching As and For Praxis. Change agency through teaching as action research is a condition of "critical teaching," as is the need to draw upon basic research theory. The difference between "standards of praxis" and (mistaken notions of) standard or uniform practice is explained and points to a professional community of shared standards for guiding individual praxis. A praxial theory of music and musical value leads to the conclusion that teaching as praxis means teaching for praxis-i.e., teaching

Regelski, Thomas A. 2020. Tractate on critical theory and praxis: Implications for professionalizing music education. Action, Criticism, and Theory for Music Education 19 (1): 6-53. https://doi.org/ 10.22176/act19.1.6 
must bring about the ability and desire on the part of students to engage in music as a praxis that is "basic" to the life well-lived.

\section{Traditional Theory: Scientistic Positivism and Technicist Rationalism}

Scientism

Empiricism, the basic philosophical paradigm of science, came into prominence during the 18th century intellectual and philosophical activity known as the Enlightenment. It holds that knowledge is gained only through the senses. Positivism (sometimes called logical empiricism, scientific empiricism, or scientific positivism) takes empiricism to an extreme by claiming that whatever cannot be verified by sensory experience (as observable 'positive' knowledge) cannot be explained, is unknowable or unreliable, and is thus not true knowledge. Positivists argue that the scientific method is the only source of valid, objective knowledge about reality-a claim labeled scientism by critics, including Critical Theorists. Scientistic positivism, in effect, holds that non-scientific claims to knowledge are meaningless, misleading, subjectively variable, and thus capricious and dubious.

In use, positivism has faith only in the scientific quantification of 'objective' data and the corresponding use of statistics to state "laws." The laws thus "discovered" in nature are used to make predictions: laws are "true" (i.e., scientific, objective, valid, reliable, 'positive') to the degree that predictions turn out as the laws forecast. Positivists hold that anomalies not predicted by present laws will eventually be covered by better, more comprehensive laws as they are discovered. Scientistic positivism has also traditionally rejected as meaningless (in the sense explained above) statements in the social sciences, arts, and humanities about the qualities or activities of "mind" and human subjectivity. In particular mentalistic, subjective states such as ideas, intentions, and feelings are denied or devalued. Scientific behaviorism, for example, is a key example of this tendency and thus explains all human consciousness in terms of observable behavior. It excludes reference to mental events or covert states, or to the subjectivism of introspection of any kind; and in radical form it even denies the existence of mental states. Thus words such as "feeling," "choosing," "intending," (etc.) are held to have no objective referents; their "meaning" (a condition that positivists in general have trouble

Regelski, Thomas A. 2020. Tractate on critical theory and praxis: Implications for professionalizing music education. Action, Criticism, and Theory for Music Education 19 (1): 6-53. https://doi.org/ 10.22176/act19.1.6 
explaining) is "seen" only in reference to overt behavior or dispositions for overt behavior.

In the physical sciences, positivism results in laws and predictions about natural "things." Its results permit control of these things through technology and rationalized or scientized management techniques. Despite the important difference between "things" and people, social scientists have often tried to gain status as "scientists" by modeling their research on the positivist assumptions and practices of the physical sciences. Whatever the importance of such "basic research" theory, it is easily abused when mistakenly applied as law-like technologies of human functioning (e.g., social, economic, political or learning "theory" acted upon as "fact"). It is worth noting here that because it is modeled on the assumptions of positivistic-oriented social science, the preponderance of empirical research done in music education has often been neo-behaviorist and thus positivist in its assumptions, practices, and results. Despite its complexities, human behavior is seen as ultimately responsive to statistically determined natural laws by this particular group of empirical researchers in music education and by positivists in the social sciences in general. And, it follows, what is predictable is ultimately controllable through rational means, systems, and 'standards'.

\section{Technicism}

Rationalism, the belief in reason as a source of reliable knowledge, also came to full flower during the Enlightenment. Originally the use of reason emphasized by Enlightenment thinkers was opposed to "authority" or "revelation" as sources of knowledge-in particular, the authority of the Church and of kings. The Enlightenment thus brought Western civilization out of the "Dark Ages" and initiated the "modern" era in history and the associated paradigms of what today is called modernity.

However, empiricism and rationalism converged during the Enlightenment in certain ways that excluded other possibilities. These directions ultimately led to: (a) the rise in the scientific method for determining valid knowledge; (b) the rise of technology and the resulting paradigm of technicism and its uncritical faith in "what works" kinds of techniques for applying such supposedly objective knowledge to solving human problems; (c) and, above all, the belief in the rational perfectibility of society through just such 'management techniques' or 'methods'.

Regelski, Thomas A. 2020. Tractate on critical theory and praxis: Implications for professionalizing music education. Action, Criticism, and Theory for Music Education 19 (1): 6-53. https://doi.org/ 10.22176/act19.1.6 
Thus, as shall be illustrated below, when scientistic assumptions are applied to education, learning is assumed to be subject to objective and invariable laws referred to by the benign though misleading term "learning theory." And when technicist inspired rationalism applies such laws as "what works" techniques, teaching comes to be considered a technology of methods by which the learning process of learners is controlled. Teaching thus becomes a technicist undertaking rather than a professional praxis.

In the next section scientism and technicism and the "false consciousness" that results from blind acceptance of the positivist-modernist ideology of scientifictechnical 'progress' are contrasted to the "critical consciousness" advocated by Critical Theory. Such a critique reestablishes the fundamental importance of the kind of personal agency that is situated-a condition that is central to both teaching as professional praxis and to music as a human praxis.

\section{Critical Theory}

Critical Theorists have been critical of the scientism and technicism that have resulted from the misuse of the empiricism and rationalism bequeathed by the Enlightenment. While seeing empiricism and rationalism as potentially productive, Critical Theorists identify an inherent and unresolvable tension between these twin strands of post-Englightenment modernity. While not wishing to overthrow modernity altogether (as in the case with postmodernism), Critical Theorists such as Habermas conclude that misapplications of rationalism and empiricism (e.g., rationalized political theories such as communism; technicist teaching "methods" and scientistic "learning theory") have produced largely negative results. These theorists observed first-hand the extremely negative results of modernism seen during and after World War One, the world-wide economic 1930s "Depression," and as a result of the rise of Nazi Germany and World War Two. In fact, the latter necessitated the departure of Critical Theorists (and other scholars) for the United States for the duration of the war. (This University in Exile became later known as the New School for Social Research.) Even after their relocation they noted critically that science and technology had produced negative results that would long outlast this or that war-for example, the hubris of the technocrats who designed, and the blind credulity of the passengers who sailed on, the supposedly unsinkable,

Regelski, Thomas A. 2020. Tractate on critical theory and praxis: Implications for professionalizing music education. Action, Criticism, and Theory for Music Education 19 (1): 6-53. https://doi.org/ 10.22176/act19.1.6 
but nonetheless ill-fated Titanic; or, more recently, environmental and ecological problems of industrialization.

\section{Loss of Freedom}

They argued in particular that the average person unwittingly forsakes his or her freedom by uncritically having faith in false claims that scientism and technicism promote rational social and economic planning and thus predictable progress towards a free, compassionate and ever-more perfect world. Such ultimate progress clearly has not happened; for example, who among us feels they live a happier more fulfilling life than, say, the Amish? And the "average" person is generally skeptical of the claims made for modernity-a disappointment and frustration that is, for example, reflected in the tidal wave of both religious and secular conservatism worldwide and in various forms of social unrest. Nonetheless, people continue to have uncritical faith in modern science and technology. The corresponding unwillingness or inability to take responsibility for their own lives is seen, for example, in their manipulation by media-driven values, 'taste-makers,' cult leaders, and ideological 'movements,' 'systems' and 'institutionalized' groups of various kinds. In this view, people everywhere can generally be described as, in the words one analyst used to describe the situation in the United States, a "nation of sheep." In sum, unfreedom alone has progressed.

Similar conclusions are also reached by postmodernists, a diverse group of thinkers who point out the limitations and social situatedness of reason and science and thus argue that modernity has or should come to an end. Despite their basic agreement on the negative results of modernity (and modernism in the arts), postmodernism and Critical Theory are critical of each other. Critical Theorists such as Habermas hope to reform or repair the misapplications of rationalism and empiricism begun in the Enlightenment. Postmodernists, pointing on the other hand to the breakdown of modernity, wish to 'deconstruct' the absolute and objective truth-claims of reason and science in favor of other ways of understanding, guiding, and empowering human action.

Critical Theorists complain, thus, that people have been misled into a "false consciousness" that blindly accepts science as the only source of true knowledge and to the belief that rational (technicist) 'social planning' and the free-market can lead us to the 'good life'. The masses uncritically accept modernist claims that all

Regelski, Thomas A. 2020. Tractate on critical theory and praxis: Implications for professionalizing music education. Action, Criticism, and Theory for Music Education 19 (1): 6-53. https://doi.org/ 10.22176/act19.1.6 
human problems can be solved through technological, socio-scientific management of society, the economy, the political process, the natural resources, and human resources involving the institutions of medicine, education, and even entertainment. Thus, for Critical Theorists, scientism has led to a technology for both controlling physical things and human nature. It has denied subjectivity by idolizing false claims of objectivity and thus has become the vehicle for manipulation by ideologues who have brought about a variety of crises and suffering to modern life by imposing their own beliefs and vested interests as being in the interests of all people. The result has been the political, social and cultural subjugation of people who are denied the empowering knowledge and social conditions for becoming the authors of their own histories.

Even worse, Critical Theorists conclude, people have succumbed once again (i.e., as was the case before the Enlightenment) to various authoritarian personalities and institutions. Thus they allow political demagogues, cult leaders, politicians, scientists and, yes, even school administrators, teachers and professors to mislead them with false and deceptive ideas of 'objective' truth and 'absolute' beauty as leading to the good life. So thoroughly have people accepted their new 'chains' that, not unlike Plato's prisoners in the famous "Allegory of the Cave," they prefer their unenlightened illusions to the full light of day and thus exhibit a fear of freedom that is the result of forsaking personal responsibility for their own lives.

Critical Theorists, then, are critical of the worship of objectivity because "facts" are never impartial or unprejudiced and science is therefore never completely value free. And these theorists are particularly critical of the scientistic misuses of empiricism to deny or otherwise control human subjectivity. Thus they have been centrally concerned with the misuse and abuse of reason in social, political, economic, and ethical theories; that is, in all systems of thinking and functioning that deny personal freedom and personal responsibility. They point out that empiricism and reason have been turned back on themselves and have become the unreason of scientism and technicism.

Critical Theorists thus denounce any theory that leads, however indirectly, to practices that "disempower" human beings by taking away their own capacities for personal reason and judgment, and any theory that takes away people's control over their own lives as agents who are personally responsible for their own being and becoming more fully human. They point to the dangers of uncritically applying

Regelski, Thomas A. 2020. Tractate on critical theory and praxis: Implications for professionalizing music education. Action, Criticism, and Theory for Music Education 19 (1): 6-53. https://doi.org/ 10.22176/act19.1.6 
totally abstract, merely "academic" theory directly to human problems. Such "academic" knowledge amounts to what Aristotle called theoria. Its danger resides in its claims to be value-free, for-its-own-sake, and thus "objective" and "true." In the view of Critical Theory, such knowledge is never value free and, because it is influenced by a controlling ideology, never simply for-its-own-sake. For example, in Aristotle's time, theoria existed to be contemplated by "free men" (not women) in the leisure time made possible by slaves, and modern researchers exchange their findings in return for professional advancement and economic gain. In fact, one criticism of positivism in the social sciences (that includes, I would argue, positivist research in education and music education) is that the resulting "journal science" contributes mainly to tenure and other career-advancement not to concrete human betterment or to basic theory. The value of what today is called "pure research" is said to be its contribution to our theoretical understanding of the world as it seems to present itself to us. Such theory can sometimes guide action, but cannot by itself determine what "goods" such human action should serve. Thus Critical Theorists are keenly alert to the likelihood in modernity for scientistic and technicist misappropriations of theory as direct "methods" and "techniques."

\section{Change Agency}

In addition to their critique of the scientism and technicism of modernism, Critical Theorists also have a constructive agenda for change. Rather than rejecting science and reason altogether as postmodernists tend to do, Critical Theorists propose to reform or repair what they see as the mess modernity has made of the Enlightenment's otherwise good potential-its agenda for jointly employing empirical knowledge and reason to improve the pragmatics of human life. They seek to actualize the heretofore unrealized potential of the Enlightenment for good. Their objective is to do so in ways that empower people to use their own reason to take more personal control of their own destinies rather than being manipulated by impersonal technologies directed by or toward technicist, scientistic control of human action. In this "critical" view, human meaning is not caused by so-called objective, natural laws or impersonal, value-free, outside forces.

For Critical Theory the "meaning" that constitutes the "good life" is internally caused, created or constituted by individuals situated in their own life-world-a situated life experience that is the result of both personal and social intentionality

Regelski, Thomas A. 2020. Tractate on critical theory and praxis: Implications for professionalizing music education. Action, Criticism, and Theory for Music Education 19 (1): 6-53. https://doi.org/ 10.22176/act19.1.6 
and that therefore involves communication with others. "Meaning" then is personally constituted within socially situated conditions; it is not handed around, passed on ready-made, or discovered "out there" in the world by science as 'given' by the laws of the universe. Each person is an agent and, by definition, an agent acts so as to achieve personal goals, needs and intentions that are necessarily situated in a context that has its own social, political, economic, and even physical meanings and conditions. According to such situatedness, then, individuals function as autonomous agents who are the "cause" of their own personal meaning (or lack thereof).

Critical Theorists are thus interested in the pragmatics of personal or critical knowledge. Such knowledge is the result of a critical consciousness-the perpetual awareness of the criteria and conditions argued by Critical Theory. Being thus critically aware of modernity's abuses of science and reason, critical consciousness provides a properly warranted source of agency in personal affairs and serves as a warranted source of change in human affairs such as schooling. Such agents understand that scientific knowledge can only help people understand "things" as they are and that science can never tell them what ought to be the case. Thus any question concerning what ought to be is unavoidably a question of values that requires critical knowledge put into practice according to the very ethical values and other philosophical criteria that science claims to avoid.

In schools, teachers who are self-empowered with critical knowledge and critical consciousness become critical educators. They help their own students rise to a level of critical consciousness and knowledge that empowers them to be more effective agents of their own personal histories. In the case of music education this would involve developing in students a critical consciousness of, for example, the economic imperatives of institutionalized and media-driven "taste makers," and would promote the kind of critical knowledge that permits an enhanced range of informed musical choices.

Critical theory, in sum, seeks to recognize (i.e., re-cognize or re-think) human subjectivity and individuality as both a means and as an end of becoming fully human, fully rational. This means that if knowledge is to be valid, it must take into account subjective, contextual, situational factors. Humans are 'subjectivities' with goals, needs and intentions, not simply 'objects' controlled by natural laws. They have reason and therefore can formulate and evaluate personal and collective

Regelski, Thomas A. 2020. Tractate on critical theory and praxis: Implications for professionalizing music education. Action, Criticism, and Theory for Music Education 19 (1): 6-53. https://doi.org/ 10.22176/act19.1.6 
purposes, goals, and values (i.e., they have intentionality). They are agents who, alone and in communication with others, can act in their own behalf or on behalf of others or society, for example in teaching.

In the next section, then, teachers who succumb to an "it works for me" kind of subjective technicism are revealed as engaging in a form of "false consciousness" that is as pragmatically ineffective in serving the music needs of students as is the "what works" prescriptions and recipes of scientistic technicism. Either form of technicism amounts to what I describe as "methodolatry"-an almost religious or cult-like attachment to particular "techniques," "methods" or "materials" of teaching that too often fall far short of the kind of effective pragmatic results that are the ethical basis of teaching as a professional praxis.

\section{Origins and Problems of Uncritical Subjectivity.}

\section{Human variability}

Considered as agents, humans are not interchangeable. Human meanings thus vary according to context, situatedness, needs, goals, and intentions. Ignoring such individuating factors reduces people to theoretical abstractions that are unreal. Whatever its value as basic or pure research undertaken for its own sake, such theoretical knowledge is so abstract that no direct application of it to human affairs qualifies as praxis. To begin with, only actions that serve humans according to the ethical criterion Aristotle called phronesis properly qualify as praxis. And secondly, in being applied to such human use, theoria becomes diluted, its abstract purity compromised and reduced by its engagement with situated values. The lowlevel knowledge that remains becomes instrumental knowledge (NB: not to be confused with John Dewey's pragmatic “instrumentalism")-a form of what, since the time of Aristotle, has been called techne or "craft." For example, compare the knowledge of the physics of electricity possessed by a theoretical physicist and an electrician; the knowledge of chemistry possessed by a theoretical chemist and a medical doctor; or the theoretical knowledge possessed by a music theorist and a performing artist. In all these instances, praxis is achieved only in possession of a distant echo of theoretical purity and abstraction.

The academic or merely theoretical quality of "pure" research is the "elsewhereness" (Shor 1992) that most teachers see in positivist research: it comes from

Regelski, Thomas A. 2020. Tractate on critical theory and praxis: Implications for professionalizing music education. Action, Criticism, and Theory for Music Education 19 (1): 6-53. https://doi.org/ 10.22176/act19.1.6 
"elsewhere" than the very places that can or need to use it. In education, it comes from the research labs in Ivory Towers, not from or even in terms of teachers on the job. Because of this "elsewhereness," teachers regularly ignore such research. Perhaps they intuit its laboratory sterility and its claims to statistical laws as lacking obvious connection with the untidy contingencies they face in 'real life' on the job. In any case, they are unable to understand the technical language of such pure theory enough to even attempt to apply it to their situations for whatever it might be worth as pragmatic knowledge.

\section{Teacher subjectivity}

Instead, "true knowledge" for most teachers-knowledge of what they like to call "the real world"-is typically subjective: it amounts to what seems to be the case for their particular situation. On one hand, however, as far as the average teacher knows, the "real world" of teaching begins and ends with her classroom. On the other hand, she assumes (unfortunately, in error) that other teachers experience more or less the same "reality"-that schools and teaching are basically the same except for minor local differences, and that teaching situations are similar for most teachers in other classrooms and in other schools. Thus the "elsewhereness" of positivist research is rejected in favor of a radically subjective "hereness and nowness" where particular teachers are typically 'in touch' with only their own teaching circumstances, their own ideas and their own personal and teaching paradigms. Each, thus, does his or her "own thing" and the modern school amounts in effect to " $x$ " number of one-room schools under one roof. As a result, "school systems" (note the technicist claim) function as collections of individual 'operatives' who are assumed to be contributing uniformly to a collective 'system' when, in point of fact, this is not the case at all.

One problem tends, unfortunately, to be commonplace: Lacking any consensus concerning tangible and pragmatic outcomes (i.e., outcomes that are useful outside of school), teachers fail to be sufficiently critical of the instruction they give in terms of its results for students and society. Actual benefits, then, are inconsistent, haphazard, variable, and unpredictable. The majority of what is learned is merely "academic"; it is relevant only in terms valued by the demands of the particular classroom and teacher, and the general program requirements of the individual school or state-wide 'system'. In other words, "academic" learning is so

Regelski, Thomas A. 2020. Tractate on critical theory and praxis: Implications for professionalizing music education. Action, Criticism, and Theory for Music Education 19 (1): 6-53. https://doi.org/ 10.22176/act19.1.6 
situated, so classroom-based, that it cannot or does not transfer to or advance outof-school musical benefits for students now and after graduation.

The following examples from the United States may or may not be applicable in the same way or degree for other countries, but they serve to illustrate how instruction that is "merely academic" can fall short of making a real or pragmatic difference in the lives of individual students and thus falls short of being professional praxis comparable to the other helping professions. Thus, even though students in the United States typically have classroom music instruction for 6 to 8 years, few gain any functional music skills, or any musical independence; for example, the average "graduates" of general music classes cannot read music effectively for personal purposes. Nor do they typically develop a disciplined "taste" for any kind of music as a direct result of schooling. The vast majority who have been in ensembles (perhaps only $15 \%$ of the school population to begin with), lack the independent musicianship to be active performers and the few that have such competency-usually the section leaders-do not seem to have learned to value active performing enough to make time for it in their lives (in the way, for example, amateur athletes continue to use their physical education). They do not remain musically active after graduation as performers or listeners; and they otherwise fail to show themselves to be musically different or improved in any way that can be directly attributed to their ensemble participation-beyond, arguably, its strictly social benefits as a school "activity."

Similar and other ineffective or merely academic results can doubtlessly be pointed out for other countries. Faced with such disconcerting examples, music teachers place blame on the students (e.g., that students lack talent, intelligence, a work ethic, etc.), parents (they are too lenient, too uninvolved, and don't make their children practice), society (it doesn't value education and "good music"), television (it diverts them from studying and practicing), and other scapegoats such as interscholastic sports, after-school jobs, and the like.

\section{Technicist Teaching}

It is true that there are many individual and social impediments to public schooling. However, teachers are all too accustomed to blaming these forces and rarely look to their own instruction as the primary source of poor results. As seen by too many teachers, then, poor learning is not a matter of the technology of traditional

Regelski, Thomas A. 2020. Tractate on critical theory and praxis: Implications for professionalizing music education. Action, Criticism, and Theory for Music Education 19 (1): 6-53. https://doi.org/ 10.22176/act19.1.6 
methods and techniques they use for instruction. They take for granted that this technology of traditional "tools" serving traditional and taken-for-granted ends has been passed on as a craft of teaching from one teacher to another. The common wisdom holds that such traditional methods have been "proven" successful by the "test of time." Teachers tend, therefore, to teach as they were taught! This includes, especially, teaching as they were taught to teach in their "student teaching" internships and, in general, by the "culture" of teaching that uncritically passes on teaching paradigms as technicist methods. Methods thus become taken-for-granted recipes and prescriptions used without regard for results.

Because such teachers assume that the competent delivery of the "good methods" sanctified by tradition or a particular institutionalized advocacy group automatically guarantees "good results," they tend to focus on a quest for such activities and ideas to use. In consequence, aside from keen attention to whether students are generally cooperative, teachers too often ignore the goodness of results in terms of students' actual musical competence and attitudes. As long as there is no major misbehavior, then, results are uncritically assumed to be good or good enough. That a lesson was merely practicable-i.e., could be "delivered"-becomes the criterion of "it works," not whether students have the pragmatic ability to do anything new, better, or more often as a result of such instruction. Thus "delivering" or providing "instruction" is uncritically assumed to amount to "teaching."

With the confusion introduced by this verbal self-deception, one's "teaching" is effectively disassociated altogether from the criterion of whether one's students are able to demonstrate valuable "learning." The process called "teaching" becomes uncritically equated with the product called "learning." As a result, "teaching" becomes nothing more than a certain generic process a person labeled (i.e., certified) a "teacher" undertakes, not an action or professional praxis qualified in terms of the results brought about for students. The very nature of a profession, particularly "helping professions" such as medicine, law, therapy, dentistry, nursing, teaching, and the like, is to bring about predictable and tangible benefits for the individual clients served. In this sense, a physician whose patients regularly remain sick or get sicker is a "doctor" in name, not in fact. And, applying the example to schooling, when instruction results in "clients" who remain "sick" or get "sicker"-that is, where there is no predictable or valuable learning on the part of students-

Regelski, Thomas A. 2020. Tractate on critical theory and praxis: Implications for professionalizing music education. Action, Criticism, and Theory for Music Education 19 (1): 6-53. https://doi.org/ 10.22176/act19.1.6 
"teaching" is equally a misnomer. What is called by that name is a certain going through the motions, not a praxis that is defined in terms of the results brought about.

\section{Rationalization of music and teaching}

That this conflating of "instructing" with "teaching" exists at all is another unfortunate consequence of modernity run amok. Before the modern development of what sociologists misleadingly call "the professionalization of teaching," a "teacher" was any person from whom a student learned. The student was, in every sense of the word, a "disciple" of both the teacher and the teaching, and the idea of the scholarly "disciplines" still conveys the sense of being a life-long student of a field of inquiry or action. However, with the Enlightenment's dictate for rationalism, all knowledge-along with virtually every aspect of society, including musicwas subjected to rationalization. It was thus analyzed, dissected, labeled with technical terms, theorized and codified into "disciplines" and collected in books such as the crown glory of the Enlightenment thinking, the first Encyclopedia. The aestheticizing of music by aesthetic theory is a key and relevant case at point.

A related type of rationalization or relevance to music educators in the Eurocentric tradition is the invention and subsequent development of the "theory of music" as a "discipline." This was also initiated during the Enlightenment, mainly by Rameau, one of the "Encyclopedists"-theorists and "philosophes" involved in compiling the first Encyclopedia in 1751. This "theory of music" systematically rationalized and standardized the "common practice" of its time, yet is still taught today as "fact" in 'theory' and 'harmony' classes in high schools and universities despite its general irrelevance to contemporary musics of just about any kind or genre-with the possible exception, ironically, of very simple rock and pop musics. In fact, "music" can no longer be accounted for in terms of any traditional, all-embracing, universal or essentialist theory. Rather, with the postmodern explosion in the late 2oth century of a pluralism of "musics," there is no longer any semblance of "common practice." In any case, "common practice" was at best a misnomer describing a certain rarefied and 'uncommon' taste for European "art music" during a limited period in history. Thus despite the attempt to define "music" as a singular "thing" or process, or similar attempts to define an aesthetic essence for all music, such singular, universal or essentialist definitions of "music" simply no longer

Regelski, Thomas A. 2020. Tractate on critical theory and praxis: Implications for professionalizing music education. Action, Criticism, and Theory for Music Education 19 (1): 6-53. https://doi.org/ 10.22176/act19.1.6 
obtain when the pluralism of postmodern musics is properly recognized. These musics, each a separate praxis with its own unique characteristic qualities and criteria of musicianship and artistry, thus give lie to the pretense that any aesthetic theory of musical essentialism can rationalize either the value of such musics or can serve to guide them in praxis.

Teaching has also experienced a similar process of rationalization and systematization-the earlier mentioned "professionalization of teaching." Beginning once again in the Enlightenment with such thinkers as the philosopher and Enclyclopedist Jean Jacques Rousseau, treatises and theories were issued in increasing numbers. And especially in the last century empirical findings and theoretical conclusions from a variety of scholarly disciplines have been applied to educational theorizing. In addition, "schooling" itself became rationalized-formalized, systematized, and institutionalized-as "education," such forces themselves being a direct consequence of the modernist paradigm that arises from the standardizing rationalism spawned by the Enlightenment.

"Teaching" thus became a job description or an employment category in the field or business of "education" more than it described a successful praxis that resulted in a valuable product. And with the "training" of teachers in university departments of education we see this most important human activity itself subjected to a process of rationalization, systematization, standardization (i.e., graduation and certification 'requirements') and (supposedly) efficient assembly-line production techniques. This so-called professionalization resulted in the "certification" or official labeling of a standard operative called a "teacher"-a status that is too often quite irrespective of the individual's ability to produce positive and functional results for students. The term professionalization was thus adopted early on by sociologists solely in consideration of the rationalization of teacher-training and the subsequent certification or licensing of teachers. As a result, it should not be confused with the need to reconstrue teaching as a professional praxis along the ethical and other pragmatic criteria typically advanced for the other major professions.

To be a "teacher," in the modern view, is to be "certified" to engage in a subjectively determined and fixed, technicist process called "teaching" that focuses on the competent use of "good (i.e., 'standard' or 'traditional') methods." Evaluation of students (for example, "grades"-another invention that results from the

Regelski, Thomas A. 2020. Tractate on critical theory and praxis: Implications for professionalizing music education. Action, Criticism, and Theory for Music Education 19 (1): 6-53. https://doi.org/ 10.22176/act19.1.6 
quantifying and systematizing practices of modernity's rationalism) uncritically assumes "teaching" with "good methods" and leads to the conclusion, "Well, I taught it to them; if they didn't learn it, it is their fault!" Thus the methods and materials are taken for granted as "good" and, as shall be explained more below, the curriculum is equated with the simple use of those methods and materials (a situation comparable to turning on and going through the motions of using a vacuum cleaner without determining if the rug is actually being cleaned). Unfortunately, neither the methods nor the curriculum are ever evaluated in terms of the goodness of actual results in terms of benefits for students or society. The paucity of these results for "education" in general are thus increasingly commented on and criticized by everyone from politicians to taxpayers.

Music educators not only share in this criticism; some, particularly in secondary schools and higher education, are further criticized for their preference for working only with the elite, select, 'talented' few-a situation somewhat akin to a doctor who prefers only healthy patients! Whatever the paucity of results may be in terms of students' mastery of cognitive and psychomotor skills, then, most music teachers, as is the case with their colleagues in other disciplines, seem to believe that such poor results are good or good enough under the circumstances. They accept that whatever results they manage to produce are rationally all that can be expected and, therefore, that such results are the 'reasonable' by-products of the competent use of good methods. However, as we have seen, when certain takenfor-granted methods are used to produce taken-for-granted (i.e., not critically analyzed) ends, a technology of teaching comes into being. The result is an almost religious belief in and thus a search for particular methods, "activities" and materials that are believed "to work." "Good teaching," in this uncritical, technicist view, is judged solely in terms of the efficient delivery of "good methods" and use of "good materials."

\section{"Methodolatry"}

Such methods and their related materials can be characterized into two general types: institutionalized and individualized. Each of the former type involves a 'standardized' technicist 'system' of techniques and materials that is widely adopted and followed along what are assumed to be uniform lines. Each such 'system' of uniform methodological practices meets all the standard criteria of a social

Regelski, Thomas A. 2020. Tractate on critical theory and praxis: Implications for professionalizing music education. Action, Criticism, and Theory for Music Education 19 (1): 6-53. https://doi.org/ 10.22176/act19.1.6 
institution: taken for granted paradigms that generate equally taken for granted practices and values; legitimation procedures that advocate the institution's existence when actual results fall short of claimed values; proselytizing machinery for attracting and then initiating new conscripts; a historicity of approved, traditional practices that are passed on as "good" and accepted unthinkingly by conscripts as received wisdom; and, of course, experts who function as 'managers' of the institutional knowledge base, guardians and defenders of the status quo and gatekeepers for controlling admission. Institutionalized methods, for all their claims to technical or systematic uniformity and standards, are nonetheless highly idiosyncratic in practice and eclectic in key ways dictated by the varying contexts and situatedness of teaching and learning and music, and by musical and personal differences between teachers. But the collective belief in and common discourse about "the method" even more strongly commits adherents and converts to the shared technological view of teaching. The sheer number of "believers" or "disciples" thus leads to an almost religious faith in the method that can be dubbed "methodolatry."

Individualized methods, on the other hand, are developed by particular teachers from components of systematic methods, the eclectic methods of other teachers, and their own trial and error. They tend to be so personal, so idiosyncratic, so eclectic, so governed by the here-and-now of their situatedness, that two such teachers have very little in common. Thus discourse between them is typically very unproductive. More unfortunately, once formulated, an individualized method typically becomes rationalized, systematized and standardized into a personal technology of "what works for me" that is assumed to be "good teaching." Thus the teacher assumes that because his methods are good, the results must also be good and, as with institutionalized methods, the goodness of results gets overlooked.

With either type of method, curricular ends are taken for granted and are not critically analyzed or stated in unequivocal, observable terms. The simple use of the method and its associated materials is equated with curriculum. Simply using or "teaching the method" (e.g., "I teach the method") becomes "teaching the curriculum." Thus the process is automatically assumed to be the product and the medium becomes the message. In other words, "teaching" this or that "activity" may produce a certain degree of collective musical "activity" on the part of students during class, but little or no degree of personal musical agency results for

Regelski, Thomas A. 2020. Tractate on critical theory and praxis: Implications for professionalizing music education. Action, Criticism, and Theory for Music Education 19 (1): 6-53. https://doi.org/ 10.22176/act19.1.6 
individual students outside of or after graduation from school. Now if carpenters thought in this way, they would claim that simply using their "tools" amounts to "building." With no "blueprint" in mind, then, they could simply chisel, saw, hammer and screw things together and still consider themselves to be "builders" despite the fact that their efforts never build anything useful. Many music teachers, with comparable assumptions in mind, similarly employ what they subjectively consider to be their "good methods" or "good tools" of teaching without a clear curricular "blueprint" to guide either their instructional efforts or to serve as the basis for evaluating the success of such instruction and of students' learning.

\section{"Endullment" of students}

In practice, then, results too often are not critically observed to empower students musically for life. Negative results and other unintended side effects often worsen the situation: for example, poor attitudes toward the irrelevance of music class itself; or, in ensembles, the averaging effect of large numbers that masks the musical weaknesses of individuals. To once again use a comparison from the health professions, not only don't many patients get well as a result of treatment, they get sicker! Thus, to refer again to an example given earlier for the U.S., instead of developing "musical literacy" (i.e., student graduates who can all read, write, perform, and understand music better as a result of their musical schooling), students too often give every indication of having been "turned off" in general music class to such matters. Instead of gaining an "aesthetic education" (and whatever that might be, and how it is to be observed as evidence of successful teaching and learning are, of course, not specified), the result is an anesthetic education. Thus students too regularly are "endulled" and often undertake a "performance strike" (Shor, 1992)-a work stoppage or suspension of effort-and resist or reject and thus "tune out" or ignore what is taught in terms of their own musical functioning outside of class. And in ensembles, they either ignore practicing their instruments (preferring to use the ensemble as a social club) or quit studying or even playing instruments altogether. Typically the results are of the sort that all but guarantees that students will have little to do in their lives with the kinds of music studied in school. In any case, the musical skills, understanding and appreciation of typical school graduates extends no further than the informal tastes "educated" by the mass media.

Regelski, Thomas A. 2020. Tractate on critical theory and praxis: Implications for professionalizing music education. Action, Criticism, and Theory for Music Education 19 (1): 6-53. https://doi.org/ 10.22176/act19.1.6 
Thus such music education fails to promote the kind of musical independence that could serve students throughout life.

In section four, after a recap of Part I, an account of praxis as a basis for professionalizing music education is offered. The need for ongoing ideology critique is also advanced as an ethical condition of the "critical consciousness" of professional problem-solving and responsibility that needs to replace the "false consciousness" of ideology-induced technicist teaching. And, most centrally, the importance to praxis of a warranted and well-designed curriculum are argued.

\section{PART II}

\section{Recapitulation}

From the perspective of Critical Theory, being a teaching professional involves analyzing the kind of scientistic positivism (seen in section one) in terms critical of a technology of teaching (seen in section two) that denies the subjective particulars of individuals teachers, individual students and the situatedness of all teaching and learning. But, as explained in section three, the teacher as a professional is also critical of the "it works for me" kind of hand-me-down traditionalism where the criterion of what "works" has been defined more in terms of students who appear to be cooperative, having fun (etc.), than in terms of pragmatic outcomes that empower them to be the agents of their personal musical lives. Whether inspired by scientism or traditionalism, that a method is practicable only means that it can be put into practice (i.e., has some history of past practice), not that it is pragmatic in terms of the beneficial results it brings about. Thus Critical Theory points to the need for teachers to be professionals engaged in praxis. This necessitates attending first and foremost to the goodness of results brought about for our "clients"-i.e., the students.

\section{Curriculum: Ideology versus a Phronesis of "Good Results"}

Professional praxis

Professions, properly understood then, are not just specialized or skilled types of employment. A profession is a praxis and, in distinction to just any 'practice' or 'habit', a praxis is characterized and guided by a condition Aristotle called

Regelski, Thomas A. 2020. Tractate on critical theory and praxis: Implications for professionalizing music education. Action, Criticism, and Theory for Music Education 19 (1): 6-53. https://doi.org/ 10.22176/act19.1.6 
phronesis. This is the ethical criterion for "good results" that guides a professional practitioner to a primary concern with the pragmatic benefits experienced by the typical client. In the case of music education, individual students in music classes and ensembles are the clients served (i.e., not just the class or ensemble as a collectivity). "Good praxis" (i.e., good teaching practice) in this "critical" view, can be judged only in terms of such a phronesis of "good results" for students. And "good results" are seen in terms of the degree to which, in the case of music teaching, individual students have been enabled as a result of their musical schooling to want to and to be able to engage themselves in musical praxis in ways and to a degree they find rewarding and empowering in life outside of and after graduation from school.

Teaching as a professional praxis (i.e., teaching as praxis, or "teaching praxis" for short) is thus distinguished from technicist teaching, the kind of craft-based technology that Aristotle called techne: prescriptive, traditional knowledge employed in pursuit of taken-for-granted ends. Critical Theory is critical, then, of the kind of teacher subjectivity that ignores ethical praxis-practical and "good" human results for clients-by concerning itself, instead, with unwarranted reliance on methods of instruction used as a technology in pursuit of unquestioned, intangible goals (e.g., claims made for aesthetic education), atomistic taxonomies (e.g., the advocacy in the United States of "teaching to the national standards"), or other ideologically determined values.

\section{Ideological consciousness}

An ideology, as seen by Critical Theory, is a system of seemingly rational ideas, practices and paradigms that serve to justify or legitimate the values, vested interests, and indulged beliefs of a particular group. Such groups either operate as a "ruling class" or "dominant culture," or are engaged in some kind of "politics of recognition." In either case, the group seeks to advance its socially created realities and interests against those of other groups. In sum, an ideology advances a group's interests as being in the best interests of everyone else-even if the others who are supposedly to benefit from the ideology do not wish to have such beneficence forced upon them.

Public schooling is beset by multiple and competing political, economic, social and intellectual ideologies that function as external pressures and impediments to

Regelski, Thomas A. 2020. Tractate on critical theory and praxis: Implications for professionalizing music education. Action, Criticism, and Theory for Music Education 19 (1): 6-53. https://doi.org/ 10.22176/act19.1.6 
teaching praxis. Some ideologies, however, arise from within education generally and others from within each teaching specialty, such as the music education "establishment." Individual teachers tend to be unaware of such ideological inconsistency and interference. And they uncritically "buy into" or allow them themselves to be "owned by" a particular ideological view or claim-in music education, for example, the vested interests of the publishing industry to sell music regardless of its quality, or the negative short and long term effects of the competitions and once-a-year festivals sponsored by various teacher organizations. Thus such unsuspecting teachers invariably encounter or create for themselves an often bewildering array of ideology-based obstacles to successful praxis.

Nonetheless, many teachers remain comfortable with their pat and pet assumptions and prefer to be ignorant of and thus untroubled by criticisms and alternatives. They are unwilling, then, to undertake the kind of personal and professional ideology critique that can identify dysfunctional paradigms, taken for granted assumptions, biases and unwarranted personal theories, and other such impediments to bringing about praxial results for typical students. Instead, too many become complacent followers of the status quo, or of every fad or new bandwagon. Aside from their discomfort with the inevitable behavioral crises brought on by students who are "endulled" by the irrelevance of such teaching, they derive a certain solace from the predictability of their routines and continue in the same patterns-despite the fact that actual results often contradict the values or "goods" claimed by their curricular assumptions. An example of such a crisis would be the situation in music education where students are "turned off" to music by the very people who are trying to get them to "turn on" to the benefits study can make possible beyond what they entered the classroom knowing and valuing. Slogans and promotional campaigns by various music education organizations thus become necessary when music teaching fails to bring about the tangible and beneficial results that would be proof-positive of its value as a part of general education and its value for a life lived more fully as a result of musical schooling. Such advocacy would simply not be needed-in the current forms or degree, at least-if results promised by curricular claims of value were in fact the "goods" delivered.

Regelski, Thomas A. 2020. Tractate on critical theory and praxis: Implications for professionalizing music education. Action, Criticism, and Theory for Music Education 19 (1): 6-53. https://doi.org/ 10.22176/act19.1.6 


\section{Legitimation crises and ideology critique}

Habermas, the leading Critical Theorist of our day, has analyzed this kind of mismatch between theory and practice-between ideological claims and results (e.g., capitalism and poverty). When a system operates according to ideologies and practices that undermine its own raison d'etre, it experiences a state of perpetual crisis brought on by tensions resulting from the mismatch of values claimed for the system and values actually produced by the system. The result is a 'loss of faith' on the part of those who are supposed to be the beneficiaries of the ideology and its delivery system. Habermas calls these institutionally self-created contradictions, legitimation crises. They arise from the intractable problems and unintended negative results brought on by inherent contradictions and inconsistencies within the dominant ideology guiding the system and its 'standards'. These internal contradictions and conflicts make the benefits that are only abstractly claimed in theory progressively more difficult to justify, rationalize or legitimize as being "good." Thus, in the terminology of sociology, such 'built-in' crises bring about the need to legitimate the rationality and values of the system.

In schools and universities, for example, the hegemony of "classical music" that has resulted from the aesthetic ideology concerning music and musical value is widely under attack for its ethnocentric bias by postmodernism and multiculturalism. The result has been a legitimation crisis regarding the need for a definition of "music" and musical value that is more comprehensive and pragmatic than the aesthetic standards and values claimed for the Eurocentric canon of "art music" and High Culture. The consequence of this legitimation crisis has been pressures for a pluralistic inclusion of multicultural and world musics in schooling in order to support the claim that music is truly "basic" because it is truly relevant to the life well-lived.

Unfortunately, however, the resulting clamor for and thus rush to multicultural and world musics risks, in turn, becoming a new ideological bandwagon. Including only token examples of such music fails to put "music" in its broadest and most representative praxial sense at the core of the curriculum and this minimizes the importance of just how "basic" such musics are to life. Thus the only occasional use of these musics in public school, and the "token" and begrudging offering of a "world music" course in universities, pays only lip-service to a breadth and wealth of musics that should be a central part of all instruction that is properly called

Regelski, Thomas A. 2020. Tractate on critical theory and praxis: Implications for professionalizing music education. Action, Criticism, and Theory for Music Education 19 (1): 6-53. https://doi.org/ 10.22176/act19.1.6 
"music" education. Since broad sociocultural ideologies are at stake, music teachers are regularly subjected to the pressures of various social class interests concerning competing ideas of "classy" and "good" music, and to questions concerning which or whose music should be taught in schools, and why. Without ideology critique that can sort out such competing claims, unsuspecting teachers simply "go with the flow" and not surprisingly end up "swept away" in curricular directions that fall short of teaching as successful praxis.

The first stage of an ideology critique entails a process called immanent critique where the claims made by an ideology are used as the criteria by which the results of that ideology are evaluated. Music in schools of most industrialized nations is typically supported on the claim that it is "basic" in some way to the general education of all students. However, when the claims made by supporters of the aesthetic ideology for the benefits of aesthetic responsiveness are used as the criteria by which aesthetic-based music education is judged, it is clear that such values are not part of the general education of most school graduates whose musical tastes and habits remain virtually unaffected by such musical schooling. It is not even clear that graduates of school-based ensembles have received an "aesthetic education" since few remain musically active after graduation and since the listening tastes and habits of most have not been turned in more institutionally approved directions.

Immanent critique can similarly be used to sort out claims sometimes heard that multicultural and world musics in the curriculum somehow lead to better understanding and mutual respect between cultural groups. If in fact such music contributes only to a certain "politics of recognition" where each cultural group in a school has "its music" included in the total curriculum, students can be seen to "tune out" all but "their own" music or at most take a short-lived esoteric interest in certain musical differences from "their own" music. Results not infrequently lead to greater, not lesser musical and cultural insularity. Thus in cases like these, and others that will be characteristic of local situations (including university-level music education), where actual results contradict ideological claims, immanent critique helps teachers from being swept away by either traditions or fads that fall short of praxial results that make some tangible musical difference in the lives of students.

Regelski, Thomas A. 2020. Tractate on critical theory and praxis: Implications for professionalizing music education. Action, Criticism, and Theory for Music Education 19 (1): 6-53. https://doi.org/ 10.22176/act19.1.6 
In addition to immanent critique, teachers must also begin to use their own reason to identify praxial results that would empower students to become agents of their own musical destinies in life outside of and after graduation from school. There is always more to teach than there is time and resources to teach! Hence, the diagnoses made in and of a given situation that lead to a curriculum-or, properly speaking, the diagnoses that should lead to a written/formal curriculum-involve decisions that are always philosophical (axiological) since they rely on critical analyses of value. In music teaching, such curricular theorizing concerning musical value amounts to answering the question "What is music good for in life?" The resulting curricular problem of "What of all that can be taught is most worth teaching?" is a matter determining the most accessible pragmatic "goods" or values that music can provide for the greatest number of people.

\section{Curriculum for musical praxis}

A pragmatic answer to this over-riding curricular question rejects, first of all, metaphysical issues that cannot be adjudicated in concrete, pragmatic terms at all-or issues that do not stand up well to the process of immanent critique. Thus it does not involve fine and noble platitudes and claims about the aesthetic benefits of music that cannot be evaluated in terms of teaching success or in terms of the benefits of the lives of individual students. To be successful, curriculum cannot succumb to the legitimation crises created by the use of aesthetic theory and its claims of "aesthetic disinterestedness," "aesthetic distance," and "for-its-own-sake" kinds of musical purity, while at the same time claiming that music education as aesthetic education is somehow basic in a pragmatic, useful sense to general education. Thus, a pragmatic curriculum-a curriculum for music as praxis-will not reflect the kinds of aesthetic claims that involve the increasingly problematic legitimation crisis concerning elitism versus populism-good taste versus popular tastes-and the resulting problem of students who are increasingly turned off to the kinds of "good music" that are alone claimed to have appropriate aesthetic benefits.

Instead, a pragmatic curriculum will be guided by a phronesis of "personal action" with music. Music in this praxial sense is "for" personal praxis or agencythat is, for creating or experiencing "good time" in life through music. "Good time" is time well spent-the word "worthwhile" literally means "good time"-and thus

Regelski, Thomas A. 2020. Tractate on critical theory and praxis: Implications for professionalizing music education. Action, Criticism, and Theory for Music Education 19 (1): 6-53. https://doi.org/ 10.22176/act19.1.6 
musical agency is an important means by which humans make a life worth living. A curriculum predicated on the "good time" occasioned by musical praxis will thus take into account how people can typically avail themselves of music in ways that improve the quality of their lives over what would have been the case without musical studies as part of their general education in school.

In other words, a curriculum for musical praxis is first and foremost concerned to ensure that students want to and are able to avail themselves of a wider and altogether richer variety of musical choices for enriching their lives than would have been the case without formal schooling. For Critical Theory, then, the ethical criterion of successful, professional teaching praxis in music education-i.e., the phronesis of a curriculum predicated on authentic praxis-will be to empower students to improve the quality of their lives through music. "Good music" will be seen or evaluated according to the incredible breath of "good results" that music considered as praxis can bring to humans being and becoming human.

Such a praxial theory of music, then, is not exclusive; for example, in the way major aesthetic theories exclude as properly or fully aesthetic "popular" and other "worthwhile" musical praxes such as Christmas songs, folk music; much admired "non-classical" instruments such as the accordion, guitar, and other indigenous instruments; music used in religious worship, music for dance, advertising, film and television dramas, political advocacy, and therapy; as well as a host of other everyday, down-to-earth, examples of how "basic" music really is in life. Instead, a praxial theory of music is inclusive of just such countless important ways in which musics of all kinds and types serve humankind-including "concert music" of all kinds presented to audiences for "just listening." Music as praxis serves not just solitary individuals who listen to music as a self-sufficient action, as is the case with the "art music" tradition of Eurocentric concert music. Instead, it also encompasses all types of musical praxis that serve individual and social needs and usesfor example, music for weddings and other ceremonies and celebrations.

Furthermore, music as praxis includes and advances all kinds, degrees or skill levels of individual, recreational, and amateur music-making, and all such genres of music involved in creating such "good time" as valuable or "good" for the individuals directly served. It is therefore not restricted to just the "classy" music of any style or genre, or to performance standards of professional "artists" and other "experts." A praxial view of music also properly recognizes that music carries an

Regelski, Thomas A. 2020. Tractate on critical theory and praxis: Implications for professionalizing music education. Action, Criticism, and Theory for Music Education 19 (1): 6-53. https://doi.org/ 10.22176/act19.1.6 
inescapable and important sociality. "Just listening" as an audience member, for instance, is not simply a matter of "listening alone" among others; it is inherently a social experience occasioned by music. Thus it includes the social communality of the audience as part of the "meaning" experienced in connection with the music.

Even listening alone at home takes part in a social universe of meaning: aside from the fact such recorded and broadcast music presumes a "virtual" audience (i.e., taste public), the facticity of the music of the moment itself-the social process by which individuals regard it as a "thing" or a "work"-inherently presumes institutionally sanctioned and culturally created meaningfulness. This sociocultural component extends to the "meaning of music" itself which, in the praxial view, is thus not exclusively internal, intrinsic, or for-its-own-sake as claimed by the dichotomizing categories of aesthetic theory. It is instead inclusive of an almost unimaginable variety of social and cultural meanings, intentions, influences and traits that importantly include the broader and ultimately situated influences of society and culture and the inherent sociality of sound and its use (or misuse).

"No man is an island" it has famously been said. And, in the praxial view of music, the isolated or autonomous audience member is thus a fiction aesthetic theory has taken for granted as part of the larger European paradigm that stresses the isolated individual and correspondingly ignores or minimizes the social amplifiers and determinants of culture and the communal "we" intentionality that conditions any lifeworld. Furthermore, the idea that a "work" of music is self-referential, forits-own-sake, or otherwise an autonomous "expression" of the composer's (or humankind's) "inner life" that is isolated, cerebralized, and reified as the absolute (and absolutely Good) formal or expressive meanings claimed to be "in" a scorethis idea is equally unwarranted and oversimplified. The "feelings" accounted for by praxial theory are visceral, affective experiences far more direct, immediate, down-to-earth and basic than the typical high-minded claims made for the cerebralized, intellectualized, and aestheticized "forms of feeling" or "pure forms" promised by leading aesthetic theories (e.g., "absolute music").

With a curriculum in mind that is rooted in the realities of ubiquitous musical praxis that is thus "basic" to the lives of typical people (i.e., not only professionally trained musicians), the question "What is good music?" is answered merely in terms of how well this or that music serves the particular "goods" (values) identified in the curriculum as advancing "good time" and thus the "good life" through

Regelski, Thomas A. 2020. Tractate on critical theory and praxis: Implications for professionalizing music education. Action, Criticism, and Theory for Music Education 19 (1): 6-53. https://doi.org/ 10.22176/act19.1.6 
music. "Good pedagogy" (i.e., successful teaching), then, becomes a matter of how well the methods and materials serve the particular "goods" included in the formal curriculum. Thus goodness of results determines the goodness of the teaching. The curriculum itself, in turn, will be judged as "good" to the degree that its hypotheses of value-what music is "good for" in life-actually prove over time to be good "in action” (praxis) for typical students throughout life.

\section{Critical consciousness}

Starting with the ubiquity of music as basic to the good life, then, the formal school curriculum for music as praxis seeks to enhance and advance the musical skills, attitudes, and choices of students beyond what would otherwise be the case without such schooling. In order to create the conditions for such successful teaching praxis, then, critical teachers need to use their reason to identify social, political, economic, and other ideological forces that influence them and their schools in directions opposed to the desirable curricular results needed if students are to be empowered to be effective agents of their own musical destinies. By identifying such contrary or detrimental influences, individual teachers are thus empowered to become more effective agents of their own calling as teachers.

Being aware of such impediments to their success, critical teachers prepare themselves to solve problems that, for other less aware teachers, directly exert significant negative impact that typically goes unaddressed. For example, being critically alert to the negative potential of the various social, economic, political and intellectual forces seeking to dominate public schooling, a critically conscious teacher is better prepared to minimize and otherwise cope more successfully with the negative impact these forces will invariably have in each and every classroom. Critical music educators, then, will seek to understand teaching praxis in terms of local, regional, and national conditions that can divert instruction and impede the curriculum.

But, as has already been pointed out, beyond such broad-based external ideological impositions, various forces and paradigms within the field of music education itself also have important ideological overtones that can exert an equally detrimental influence on curriculum and instruction. These need to be critically evaluated as well if legitimation crises and other negative effects are to be avoided or minimized. As we have already seen in earlier contexts, these ideological forces

Regelski, Thomas A. 2020. Tractate on critical theory and praxis: Implications for professionalizing music education. Action, Criticism, and Theory for Music Education 19 (1): 6-53. https://doi.org/ 10.22176/act19.1.6 
typically involve the narrow-minded and uncritical acceptance of ideas, theories, practices, values and the like that have great bearing on teaching praxis. Rather than consider alternatives, these traditions or trends are received as matters of fact, and thus are not subjected to immanent or ideology critique, despite the negative potential for the technicist harm pointed out earlier. Evidence of these kinds of potentially detrimental influences are seen at all levels of music education.

Take, once again, the example of a "what works" technological or technicist approach to teaching that was analyzed earlier in relation to scientistic positivism. In this present context, we see it as an ideology that, in essence, claims that certain "good" methods or materials can be identified by empirical research or the "field trials' and 'traditions' of practitioners as being invariably successful-as "working"-and thus as technologically "good for" all students and society. While this is not the place to argue the issue in depth, it should be obvious that, just as the successful use of tools by a carpenter is seen only in how well built and how useful the results are, any criterion of "what works" in teaching needs to take into consideration overt curricular results. And since, as we have seen, curriculum is a matter of answering the question "What of all that can be taught is most worth teaching?" it is, in essence, a matter of values that require philosophical clarification and determination. In short, "what works" simply cannot be the value free, scientific, technological issue claimed by advocates. Rather, the criterion of "what works" needs to be evaluated according to the criterion of phronesis-that is, "what works" is strictly a matter of promoting "good results" for students.

Praxis is not reducible to algorithmic "what works" kinds of formulaic "techniques." All questions of praxis-in any profession or field of action-are determined in terms of the "presenting" context of each particular situation. In medicine, for example, diagnoses are made in terms of the "presenting" patientthe medical symptoms and other evidence shown by this patient, on this occasionand prescriptions are not routine, automatic, and interchangeable. Similarly, teaching methods and materials cannot be routine, automatic and interchangeable "prescriptions" for the same reason that even in medical practice not all prescriptions "work" well for all patients or at all for some patients. Instead, the methods and materials a teacher uses are only "tools." They need to be properly chosen and used appropriately in terms of the criteria for action provided by the builder's "blueprint"-in our case, the curriculum.

Regelski, Thomas A. 2020. Tractate on critical theory and praxis: Implications for professionalizing music education. Action, Criticism, and Theory for Music Education 19 (1): 6-53. https://doi.org/ 10.22176/act19.1.6 
For example, the MENC [today, NAfME] organization in the United States unwittingly supports and advances a technicist view through many of its activities, publications, and advocacy functions. One current example is the all-out effort to improve music teacher accountability by promoting certain "recommended activities" or "best practices" for teaching this or that item on an extensive list of institutionally created and approved "national standards." In many other countries, the imposition by ministries of education and other agencies of a variety of politically motivated programs, standards, and examinations has had similar technicist consequences. To begin with, from the point of view of teachers "in-the-trenches" at least, these standards are just one more unwelcome instance of "elsewhereness." And from the perspective of Critical Theory, this kind of hierarchy of codified, rationalized, systematized, standardized, and nationalized 'quality control' is but one more manifestation of the technicist rationality already criticized in several earlier contexts. But, in any case, despite the best of intentions, such imposition of 'standards' from on high are usually so extensive, fragmented, technical, and abstract that no teacher could ever possibly put Humpty Dumpty together in a holistic way that creates a fully functional, musical individual.

Other music teacher organizations are also culpable; for example, when state organizations advance the "what works" workshops at their conferences. These become opportunities for certain favored or self-proclaimed teaching experts to demonstrate "if it works for me it will work for you" kinds of methods and materials for other teachers in need of a quick technological "shot in the arm"-i.e., prescriptions-rather than opportunities for critical colloquy and professional analysis. Various institutionalized groups committed to the advancement of this or that name-brand "method" are, of course, also primary examples of the technicist approach to "what works." The resulting "methodolatry" is a prime example of the mistaken assumption that a method and its associated materials are, de facto, a successful and pragmatic curriculum.

"Methods" and "techniques" courses in universities based on these and other prescriptive "methods" are often particularly guilty of advancing the idea that teaching is simply a technology of techniques that once 'perfected' by practice (particularly during "practice teaching," as it used to be called) simply "work" for all times and in all places. This approach to "teacher training" fails to predicate teaching methods on appropriate prior considerations of the types of curricular

Regelski, Thomas A. 2020. Tractate on critical theory and praxis: Implications for professionalizing music education. Action, Criticism, and Theory for Music Education 19 (1): 6-53. https://doi.org/ 10.22176/act19.1.6 
outcomes such teaching "tools" are supposed to serve-i.e., the formal curricular outcomes that should serve as the criteria for evaluating the success or "goodness" of methods and materials. Hence, it is altogether rare for pre-service music education students to receive any instruction whatsoever in matters of curriculum development, in large part because music education professors are often woefully uninformed about curriculum writing and theory or have a vested professional interest in advancing only a particular method to the exclusion of all other possibilities. And in any case, the literature available in music education on curriculum theory is in fact negligible-a condition that could be either the cause for or result of the lack of such background on the part of teachers of methods and materials courses.

The lack of any foundational background in curriculum is thus a major impediment to the "student" teacher. Finally given the chance to put theory-taught-astechnological-fact into "practice" (but, unfortunately, not into praxis since the ethical imperative of praxis requires pragmatic benefits for students), the student teaching "internship" all but guarantees that neophyte teachers will be socially inducted into the "what works" mentality. At the very least they are sensible enough to figure out that "success" (i.e., "survival") and good letters of recommendation result from adopting many of the techniques used by the cooperating teacher (who, in turn, probably was similarly indoctrinated years ago).

Of course, most beginning teachers quickly discover that the conditions and circumstances of their first jobs are significantly different and that what "worked" in student teaching (or when they were students) doesn't necessarily succeed at all or in the same way in another situation-in fact, relocated "master" teachers often experience similar problems. In this regard, it is useful to keep in mind once more that the criterion of "what works" is all too often narrowly defined as not much more than "smoothly running classes of cooperative students" rather than in terms of "individual students musically empowered" to a newly enriched musical possibilities "for life." In any event, exactly how the cooperating teacher over time "modified" or "mastered" the situation to facilitate his or her methods is not something the student teacher can ever observe. Furthermore, since few "what works" teachers can analyze their successes, their mentoring of interns and beginning teachers is ineffective in promoting a thoughtful and reflective approach to teaching praxis.

Regelski, Thomas A. 2020. Tractate on critical theory and praxis: Implications for professionalizing music education. Action, Criticism, and Theory for Music Education 19 (1): 6-53. https://doi.org/ 10.22176/act19.1.6 
One important "lesson" many student teachers learn, then, is the need to adjust their first teaching situation to the "system" or "method" of "activities" they mastered during their internships-rather than, that is, adjusting the method to the situational requirements of praxis. Newly graduated music teachers often have other precedents for single-minded teaching methods since it is all too typical that in their own music lessons in the university or conservatory they were expected to adjust to the pedagogy of their teacher. Few studio teachers have developed a range of pedagogical approaches that meet the needs of students, and a single-minded "what works" approach to musical instruction is unfortunately a paradigm that is difficult for new teachers to resist.

As a result, music teachers typically begin their careers with this model of adapting students and the teaching situation to the needs of the teacher and his or her preferred technology of methods rather than determining the methods that best suit situated curricular needs. Moreover, curriculum is tacitly based on the technicist models of student teaching. Thus the average music teacher begins a career without either a formal (i.e., written) curriculum of his or her own or without any intention of evaluating the de facto curriculum that is instead the haphazard result of the instructional model provided by the student teaching internship. Instead, because the first teaching position demands more or other than what sufficed during student teaching, the beginning teacher is focused from the first on finding, using and "practicing" various "canned" or "teacher-proof" lessons and "activities," numerous recommended "bags of tricks," and other technicist prescriptions-many suggested by well-meaning older teachers themselves in the uncritical grasp of technicist assumptions.

As in student teaching, "success" will be judged against the 'norm' of cooperative students and smoothly running classes, not in terms of actual musical benefits for the long run in the lives of individual students. Student teaching as presently institutionalized contributes to this less than satisfactory result by its almost single-minded concern with individual class lessons or rehearsals and its corresponding lack of concern with demonstrations of long-term learning. Student teachers at best "plug in" to the cooperating teacher's de facto curriculum. Even if a formal curriculum can be produced for the student teacher who dares to ask to see it, the student quickly notes that it is either not followed at all, or is not "delivered" as designed and thus plays no role in the evaluation of students or of teaching success.

Regelski, Thomas A. 2020. Tractate on critical theory and praxis: Implications for professionalizing music education. Action, Criticism, and Theory for Music Education 19 (1): 6-53. https://doi.org/ 10.22176/act19.1.6 
Thus instruction by student teachers is rarely evaluated in terms of where or how well the formal curriculum is actually "covered," and even more rarely evaluated in terms of whether claims as to the value of proposed curricular outcomes are verified as being truly "good for" empowering students to get into action musically in ways that can be attributed directly to their musical schooling. Furthermore, because college supervisors see only random samples of individual lessons or rehearsals, evaluation of student teaching is focused almost exclusively on isolated instances of teaching, not on overall results.

All of these problems with and negative instances of ideological influences point to the need for individual teachers to engage in ideology critique at both the personal and professional levels. They simply need to identify, analyze and assess personal ideological suppositions, inherited paradigms and other tacit and takenfor-granted assumptions. In fact, from the point of view of becoming a critical teacher, this process ought to begin early in the teacher preparation process and should continue in formal ways throughout the student teaching internship. This way the habits of critical consciousness that need to be applied to one's own teaching are properly nurtured (see Rose 1994 for an example in music education).

\section{Communicative competence and collaborative action}

The collective nature of schools and schooling, however, eventually requires any teacher to cope successfully with other teachers. Thus, open, reasoned and uncoerced communication among teachers in a school-at the very least the music teachers-and between other teachers in the field of music is needed. This process of what Habermas calls communicative action must also begin in music education courses. Here, under proper guidance, students should be both exposed to and learn to deal cooperatively and collaboratively with a wide variety of different views and opinions. Thus the essentially philosophical undertaking of developing a warranted point of view based on evidence, competence with basic philosophical knowledge and processes, and clear thinking and writing, should begin in a context of diverse and plural opinions and beliefs not dissimilar from what will be experienced on the job. It should not foreclose or narrow the philosophical and practical options of neophyte teachers, for example by submitting them to only one particular methodolatry of teaching. Rather than focusing solely on single-minded and simplistic technical matters and the professor's pedagogical preferences, "critical

Regelski, Thomas A. 2020. Tractate on critical theory and praxis: Implications for professionalizing music education. Action, Criticism, and Theory for Music Education 19 (1): 6-53. https://doi.org/ 10.22176/act19.1.6 
instruction" should help expand an awareness of and sophistication in dealing with and expressing philosophically difficult matters of value and questions of praxis.

Such philosophical and communicative competence should be devoted especially to encouraging productive dialogue on curricular matters. When some reasonable degree of consensus can be reached on such matters, it can be expected, even desired, that-on the job-different teachers will be able to reach commonly agreed upon goals by different means. In other words, just as any two lawyers will approach a court case differently yet reach the same result for their clients, so teaching as professional praxis involves both an individual approach to reaching desirable outcomes and the personal and professional rewards associated with such individual achievement. The special problem for teaching as a profession, however, is the lack of easily agreed to or obviously "good" outcomes. In law it is perfectly obvious that winning the case is good, and in surgery that the patient should be relieved of pain and suffering. While there are other ethical dimensions to such professions (for example, questions of "malpractice"-i.e., "mal-praxis"), the basic phronesis by which "goods" are observed is usually quite clear.

To attain a similar status for judging the success of this or that teaching technique, curricular results in music education need to be stated in terms of regulative or action ideals. All professions are guided by such ideals-for example, in the case of medicine, to restore health, to minimize or alleviate pain and, above all, to do no harm. Such ideals are not "idealistic" in the utopian sense. Even though no perfect or "ideal" state of human affairs can ever be reached, they can be imagined. Thus regulative or action ideals are optimum states towards which people naturally strive or by which they judge the relative success of their actions (e.g., good parent, good friend). Action ideals thus guide or regulate action (i.e., praxis) by guiding it in certain directions that, being posited as ideal, are understood from the first as being incapable of once-and-for-all-times instantiation or perfect solution. For example, parental "love" or any one of the Ten Commandments is an action ideal, as is a musical score, or the physician's ideal of extending life. A curriculum, then, is an articulated and functional arrangement of such action ideals for guiding teaching praxis in the same way a score guides certain kinds of musical praxis.

A written (formal) curriculum for music thus involves hypothesizing action ideals that analyze and represent desirable, optimum states of musical functioning. It describes in holistic terms the "good results" ethically expected from a teacher's

Regelski, Thomas A. 2020. Tractate on critical theory and praxis: Implications for professionalizing music education. Action, Criticism, and Theory for Music Education 19 (1): 6-53. https://doi.org/ 10.22176/act19.1.6 
praxis (or from each individual among a group of teachers following an agreed upon curriculum) and from the curriculum itself. To be praxial, such holistic results must be "authentic" and thus capable of being put into action both in the classroom and "in life." A delivered curriculum (curriculum as "instructed" or implemented) can never fully satisfy or reach these optimum states. But, in teaching as praxis, the effective curriculum amounts to the actual results in terms of musically praxial benefits for individual students.

In this 'critical' view, then, the process of "instruction" based on "delivering" a formal curriculum is necessarily distinguished from "teaching" as a praxis that results in an effective curriculum. In the first place, a formal curriculum will be incapable of supporting effective curricular results if inappropriately conceived or written. And, in the case of where appropriate formal curriculum is used to organize and guide instruction, "teaching" results only when such "instruction" (i.e., methods, materials, evaluation, etc.) is effective in terms qualified by the effective curriculum. "Teaching," thus redefined pragmatically and 'critically', is always benefited by being drawn and inspired in the direction of such optimum results, and is judged and changed over time by using such action ideals as criteria for improvement.

Any consideration concerning action ideals for curriculum, in sum, is a philosophical undertaking. When it includes a group of teachers planning curriculum together, it also requires 'critical argumentation': the ability first to 'critique' an issue, contention, assumption or "problem" in terms acceptable to all, then to argue (in the positive professional sense) and communicate successfully the fruits of that critique in the direction of increased professional empowerment of all concerned. "Teaching," then, is not the simple use of a technology or tools of instruction; rather, it is the praxis of realizing effective results for students for life.

The "standards" of effectiveness for teaching praxis are indicated by the action ideals of a formal curriculum conceived in terms of empowering students to music as a praxis. Such standards for praxis become "common standards" when they are conceived collectively by all those in a community charged with "instructing" students. However, there need be no "standard practice" or technology for reaching the common criteria of the formal curriculum. Thus teaching as praxis is at once an individual and individualizing undertaking. "Teachers," thus, derive the kind of personal benefits and pleasures from professional praxis that are denied

Regelski, Thomas A. 2020. Tractate on critical theory and praxis: Implications for professionalizing music education. Action, Criticism, and Theory for Music Education 19 (1): 6-53. https://doi.org/ 10.22176/act19.1.6 
technicists whose efforts and results are at best more like the repeatable, routine, impersonal efforts of factory workers.

In the next section, teaching as professional praxis is seen to draw upon empirical research in generative, rather than prescriptive ways, particularly in the form of action research. The praxial knowledge guiding teaching, then, is not a matter of mere trial and error. It is shown to be a highly reflective process that results in large part from treating teaching as a type of action research.

\section{Critical Theory, Research Theory, and Teaching As and For Praxis}

\section{Reflective Teaching}

With effective ongoing communication among teachers functioning as professionals, agreement as to what should constitute an effective curriculum is progressively realized-total or perfect agreement being rare. Critical Theory then points to the need for individual and collective action plans of change agency by which such curricular agreement can be translated into the kind of teaching praxis that enhances the role of music as praxis in the lives of students. At the very least, such action plans for change and improvement need to be characterized by some degree or type of action research. Such research is not done in order to make generalizations about learning that can be used as a technology with all learners in all times and places. It is first and foremost undertaken by individuals (or cooperative groups) to improve personal (or local) teaching praxis. Any generalization of results is not considered to be law-like; it holds only for that teacher or group, in that situation, for the near future.

Action research can span a range from formal to informal. Critical and reflective teaching typically proceeds in the spirit of informal action research. Such teaching involves two levels of hypotheses that are "tested" in action. First, each "lesson plan" is considered to be a hypothesis (but need not be written). Thus the methods and material hypothesized as being "good" for advancing a curricular goal are evaluated in terms of how well observable results meet such curricular criteria. Secondly, over time, the "goodness" of the curriculum itself-the goodness claimed by its theory of particular valued action ideals-is treated as a theory that needs to be reflected on in terms of the evidence of long-term benefits for students.

Regelski, Thomas A. 2020. Tractate on critical theory and praxis: Implications for professionalizing music education. Action, Criticism, and Theory for Music Education 19 (1): 6-53. https://doi.org/ 10.22176/act19.1.6 
This kind of "diagnose-hypothesize-test-observe-reflect" process, carried on in an unending spiral called "teaching" is a rational and empirical approach to teaching that is scientific in spirit without being scientistic or technicist in its claims or procedures. More thorough and systematic formal action research will typically be reserved for major decisions by an individual or group that involve general or overall questions of methods and relevant resources-such as whether curricular ideals for music reading at the elementary level are served better by systematic instruction on classroom melodic instruments or by the more traditional singing approach. The traditional approach necessarily must cope with problems of vocal pitch matching, in addition to decisions concerning whether solfege or number systems will be used and, if so, which ones. On the other hand, since students in choruses who 'read' at all or best are most likely those who play melodic instruments, large group instruction on classroom instruments poses its own choices concerning the choice of instruments and teaching materials. The issue could be decided through formal action research rather than according to arbitrary and untested technicist claims. Only such an approach can accommodate local differences of resources, scheduling, staffing, and student profiles and needs.

Results of both formal and informal action research also can be communicated among other practitioners (locally and beyond) with a view to the possibility that the knowledge conditions of a certain practice (i.e., its "theory") can be adapted and thus 'practiced' by others along similar lines. Just as the praxis of one surgeon can be 'adapted' and 'practiced' by other surgeons, so the praxis of a teacher always has potential for being shared. Thus some teaching theories or models can become something akin to common praxis for reaching certain shared curricular resultsthat is, common standards-without the expectation of a standard practice or technicist method that is the same for everyone. Such common standards are comparable to "standards of care" in medicine and, as in medicine, there will be no standard practice that can or needs to be qualified in terms of long, detailed lists of "standards," national or otherwise. In teaching as and for praxis, then, there can be no universal technology of teaching, no slavish "teaching the standards," no "teaching to the test," no "what works" pedagogies, no uncritical adherence to ideological influences of any kind. "Good results" will be a matter of individual praxis-a praxis nonetheless informed by a community of practitioners (local and beyond) unified more by their commitment to a common standard of phronesis to

Regelski, Thomas A. 2020. Tractate on critical theory and praxis: Implications for professionalizing music education. Action, Criticism, and Theory for Music Education 19 (1): 6-53. https://doi.org/ 10.22176/act19.1.6 
get students "into action" musically than by uniform or standard teaching techniques.

Teachers also need the opportunity and the ability, therefore, to be able to analyze the action research and successful teaching practices of others critically in terms of the needs and other conditions of their own instructional situations and practices. For example, instead of "show and tell" demonstrations of discrete techniques and sample "activities" at teacher conferences, presentations would deal with descriptions and analyses of the action research process that has led to the adoption of a particular teaching praxis. Rather than presenting the praxis as a prescription or recipe, the empirical data and theoretical premises of the praxis in question would be shared and discussed in a way that would allow other teachers to formulate 'experiments' that are suited to their own teaching circumstances.

Such attempts to share praxis (in distinction to sharing technicist methods) would profitably adopt something of the format of scientific research. First would be a statement of "the problem." This would amount to an account of the formal curricular action ideals at stake and the relevant philosophical warrants supporting their "goodness"-i.e., why and how the curricular goals in question are "good." This account would allow audience members to assess the relevance or goodness of such curricular ideals in critical terms for their own praxis. Second, following this statement of the "curriculum problem" would be a review of the relevant theoretical and research "literature" that warrants the praxial application in question-i.e., the hypothesis at stake concerning whether the methods and materials are "good for" the curricular ideals at stake. It is important to note that praxial knowledge of various kinds are at stake in any such praxis, not a discrete practice presented as a method, technique, recipe or prescription. Thus this background of relevant literature would allow fellow teachers to adapt or 'practice' for themselves the practical knowledge in question-the knowledge resulting from the presenting teacher's action research-to the situatedness of their own teaching rather than uncritically adopt it as a "what works" technology.

As a third step, the student population with whom the praxial knowledge in question was developed would also need to be carefully presented as being only a "selected sample," not as universally representative of all students. On one hand, this allows audience members to make relevant comparisons and critical analyses with regard to their own student populations. On the other hand, it removes any

Regelski, Thomas A. 2020. Tractate on critical theory and praxis: Implications for professionalizing music education. Action, Criticism, and Theory for Music Education 19 (1): 6-53. https://doi.org/ 10.22176/act19.1.6 
possible implication that the praxial knowledge being shared is or can be a universal technicism. And, finally, despite the success that warrants the sharing of such praxial knowledge in the first place, results should nonetheless be critically analyzed with a view to any ongoing shortcomings that need to be improved. This would make it clear that the knowledge base for praxis being shared is not a "perfected" technique or a definitive "finding" of "what works," but rather an ongoing hypothesis that, in the best scientific traditions, "needs more research" or refinement.

In general, "methods" and "techniques" classes for teachers-in-training and inservice workshops also ought to follow these same four parameters. Teachers, in sum, need to be able to communicate their findings accurately to others if they are to create and contribute to a professional community of shared standards and a sharable fund of praxial knowledge-knowledge that results from successful praxis and that serves as a starting point for further praxis.

\section{Putting Theory into Practice}

In addition to such praxial knowledge, and despite the fact that Critical Theory has been critical of positivist claims that only science provides valid or valuable knowledge, teachers also need to be able to locate, understand and use "basic" research (i.e., theoria in Aristotle's discourse). Teaching as action research simply needs to be firmly grounded in relevant and practicable empirical and theoretical research of various kinds-especially the kind of theoretical research that draws on warrants from diverse, relevant disciplines. In general, considerable theoria of this kind already exists that can be useful in guiding teaching in the same way that basic research theory supports but does not dictate the practice of medicine. When stripped of any positivist implications that such "findings" represent or point directly to a technology of "what works," then empirical, historical, sociological and philosophical research can and should serve as part of the process by which action research for teaching is undertaken. Thus teachers should consult applicable research theory and empirical findings. And in their collegiate coursework and student teaching, neophyte teachers need be required to demonstrate this process successfully "in action."

When theoretical and empirical research is applied to teaching, it is generative not prescriptive. Such research combined with praxial knowledge generates

Regelski, Thomas A. 2020. Tractate on critical theory and praxis: Implications for professionalizing music education. Action, Criticism, and Theory for Music Education 19 (1): 6-53. https://doi.org/ 10.22176/act19.1.6 
hypotheses for likely courses of action-i.e., hypotheses that are comparable to a physician's "diagnoses"-which always must be "tested in action" and evaluated by comparison to the ethical criteria of "good results" provided by curriculum. This process of first generating such hypotheses-diagnoses, then testing and evaluating them against action ideals indicated in the formal curriculum, is the minimum condition of teaching as praxis-teaching as a profession! However, successful "tests" never become recipes. To begin with, it is not the "technique" or the "method" chosen that "works"; it is the praxial and theoretical knowledge that "works" in the hands of a suitably informed and reflective teacher to bring about musically pragmatic results.

In any case, no such successful instance is ever final or perfect; and praxial knowledge, by definition, is defined in terms of human values and needs that are forever variable. Thus the action research process is never-ending; it represents a perpetual quest for improvement that is never completed. Furthermore, teaching praxis also demands that the action ideals of the written curriculum also be treated as hypotheses; they too need to be adjudicated in terms of whether their claimed values (the "goodness" they propose) actually result in discernible benefits-i.e., whether or the degree to which musical values or "goods" result for students in "life."

Finally, although musical competence is clearly a necessary and absolutely central condition of successful music teaching, it is not a sufficient condition. A more effective, functional balance between musical praxis and teaching praxis is needed in the preparation of teachers than is presently the case. Competent musical performers are fully mindful of and thus constantly reflect on the effectiveness of their practicing in terms of praxis-i.e., the goodness of results. Similarly, music teachers become mindful and reflective critical educators and thus professionals to the degree they become more competent in applying basic research findings and curricular theory to improve their praxis.

It has been said that "nothing is so practical as a good theory." Thus, despite the fact that, since Aristotle, theoria has been undertaken and contemplated for its own sake, applied theory of various kinds and levels of sophistication is clearly necessary to guide praxis. However, it is teachers who must adapt theory into praxial knowledge according to situated criteria-just as physicians must do according to the "symptoms" of the "presenting" patient and the other conditions of

Regelski, Thomas A. 2020. Tractate on critical theory and praxis: Implications for professionalizing music education. Action, Criticism, and Theory for Music Education 19 (1): 6-53. https://doi.org/ 10.22176/act19.1.6 
their medical practice (e.g., surgeons on the battlefield "operate" under different conditions than they do in a modern medical center, yet must still get "good results"). Teachers cannot expect theoreticians and researchers to frame such research theory in universal, technicist terms, nor should they expect or accept the misleading "what works" claims of "applied research." That, from the view of Critical Theory, falls into the scientistic assumptions and ideologies of positivism and of teaching as a "what works" technology. Technicist teaching amounts to renouncing the need and responsibility of each professional to "diagnose" and "treat" each situation according to the ethical criterion of phronesis that guides effective praxis in teaching, just as in medicine or any other professional praxis.

\section{Praxial knowledge}

For music teaching to be a profession, then, there needs to exist a reasonable, pragmatic consensus within a community of professionals concerning the nature of the ideal curricular results towards which teaching praxis in music education is devoted and by which it is evaluated. From the point of view of Critical Theory, such common standards should be pragmatic in all respects. Praxis, in this professional account, thus involves an ethical commitment to getting the "right results"-meaning, in our case, musical and personal results that empower student-clients to be musical agents of their present and future musical choices. Furthermore, music teachers are professional to the degree that, through "practice," they develop a personal "feel" for practical judgment (diagnosing and hypothesizing) and decisionmaking, rather than proceeding uncritically according to received technical traditions. Thus, critical educators function as intellectual models and philosophical leaders within a community of similarly committed professionals, not as unmindful technicians or uncritical followers. They are fully aware of changing research and theory on a broad professional scale, and continually change and improve their practice accordingly. And because they learn in and from the results of their own teaching actions judged in terms of students' progress, they are their own best knowledge base.

The kind of "learning by doing" that results from the application of theory in terms of practical judgments based on ethics of praxis is referred to as praxial knowledge. Praxis generates professional personal knowledge on the part of the practitioner that is distinctly different than mere trial and error. This is why

Regelski, Thomas A. 2020. Tractate on critical theory and praxis: Implications for professionalizing music education. Action, Criticism, and Theory for Music Education 19 (1): 6-53. https://doi.org/ 10.22176/act19.1.6 
Aristotle considered praxis to be a form of knowledge and not simply any unreflective 'practice' or 'doing'. Habermas, building on this traditional view of praxial knowledge, has advanced a contemporary theory of praxial knowledge that has been applied by others to teaching as a praxis (see, e.g., Carr and Kemmis 1986).

One component of such knowledge is the realization that no praxis ever attains "final" or "perfected" methods and techniques. Instead, teachers must always be critically alert to their own fallibility. They judge their success as teacher-professionals only in terms of tangible "goods" that clearly benefit students in ways and to a degree that would not have been possible without formal instruction in schools or studios. Medicine as a profession learns (generates professional praxial knowledge) from its mistakes and failings when patients die or get worse. Teaching requires an ethic based on a formal pragmatic curriculum before teachers can similarly observe and thus learn from their mistakes and failings. The progressive elimination of such failings (however gradual), constitutes the most valuable source of praxial knowledge. The kind of progress that results from praxis, then, gives new meaning for an education that seeks to be "progressive" without on the other hand suffering from the typical criticisms usually attributed to that philosophical description.

Praxial knowledge is thus rooted in personal experience that, in turn, has been guided by informed judgments made in connection with ethical criteria that vary considerably according to the particulars of a situation. It simply cannot be passed on directly as recipes. It can only be shared in theoretical and indirect terms that need to be 'practiced' or 'developed' anew by other practitioners "in action" in terms of the criteria provided by an evolving phronesis that is itself guided by the ever-changing particulars of their different situations. Therefore, the knowledgebase at stake in "methods and techniques" courses, in methods books, and in research of various kinds, is not and should not be regarded as a fixed, final, objective, applied technology of "what works." This knowledge should be recognized as being at best a theoretical starting point for developing praxial knowledge and professional competence through ever-improved praxial success, not as a technicist collection of recipes and techniques that function as the "final word" as to "what works." And finally, the relevant "diagnoses" or hypotheses required by any adaptive application of such theory to a particular praxial situation requires a functional background in developmental and educational psychology, philosophical

Regelski, Thomas A. 2020. Tractate on critical theory and praxis: Implications for professionalizing music education. Action, Criticism, and Theory for Music Education 19 (1): 6-53. https://doi.org/ 10.22176/act19.1.6 
dimensions of teaching and curriculum, and a functional sociological familiarity with how schooling is organized. Such foundations from supporting disciplines are basic in every way to the type of diagnosis, analysis, reflection and adaptive judgment required of a music teacher as a professional.

\section{Summary and Conclusion}

Critical Theory is a particular body of literature committed to an agenda of human freedom or empowerment; a particular way of analyzing and dealing with a wide range of social problems. Unlike many other philosophies and theories (such as postmodernism's concern with linguistics and literary theory), most of the social issues addressed by Critical Theory have considerable relevance for schooling, education and teaching. It is not claimed here that Critical Theory alone can serve to reform and redirect music education. However, the increasing relevance John Dewey and other pragmatists have for Habermas puts the current literature of Critical Theory directly in touch with and relevant to current issues in education.

Similarly, the importance to Critical Theory of the need for pragmatic strategies for social change-that is, the importance of not being just another theory that cannot be put into practice-recommends it as a basis for change agency in music education. Given its central concern with issues central to music and to schooling, and because it already serves as the basis of a growing body of educational philosophy and theory (much of which is unknown to music educators), Critical Theory provides an important component for professionalizing music education that cannot and should not continue to be overlooked.

Critical teaching (i.e., "critical pedagogy") is especially well-suited to serving as a basis for needed change in music education today. It requires teachers to remain current with regard to changing bases of research, theory and praxis and to engage regularly in ideology critique. In particular it requires systematic reflection upon teaching praxis where success is judged in terms of the tangible benefits for students. This self-correcting feature prevents a Critical Theory-based teaching praxis from itself becoming an ideology, and its self-critical and reflective spirit also prevents it from becoming part of the problem that it criticizes. In sum, to be professional in terms suggested by Critical Theory means a never-ending quest to insure and improve music teaching as a praxis for bringing about the "good results"

Regelski, Thomas A. 2020. Tractate on critical theory and praxis: Implications for professionalizing music education. Action, Criticism, and Theory for Music Education 19 (1): 6-53. https://doi.org/ 10.22176/act19.1.6 
of personal musical praxis ("good time") on the part of students throughout their lives.

Teaching as praxis, then, also means teaching music for praxis-that is, for the purposes of savoring music as lifelong personal praxis. Seen from the curricular point of view, then, Critical Theory points to the importance of music itself as praxis: music's value or "goodness" and thus its reason for being in the general education of all students is to be put into action to bring about pragmatic benefits of a kind that only it can contribute to the life well-lived. Music is thus not an abstract or inert "subject" or "discipline" studied in school; it exists to be put "into action" for its fullest potential in enhancing life.

In conclusion, teaching as praxis is guided by action ideals that judge success in terms of the musical benefits brought about by musical praxis-by music "in action" in the lives of students as a direct result of their musical schooling. Music in this view is an important and basic humanizing praxis because through it "human beings become human in coming to know themselves as human" (Wartofsky 1979). Teaching music is, therefore, doubly engaged as a praxis where curriculum as a theoretical and ideal claim comes "to life" musically for students to the degree that they can put music "into action" in their lives. Music education as a profession, then, is action for a change in the musical lives of students now and in the future as adults.

\section{Recommended Bibliography}

Apple, Michael, W. and Lois Weis, eds. Ideology and Practice in Schooling. Temple University Press, 1996. A collection of important papers on the need for ideology critique in schooling.

Arato, Andrew and Eike Gebhardt. The Essential Frankfurt School Reader. Continuum Publishers, 1993. A sourcebook of important readings.

Bernstein, Richard J, Ed. Habermas and Modernity. MIT Press, 1994. An overview of Habermas with critical comments by leading philosophers, and Habermas' reply to his critics.

Bourdieu, Pierre. The Logic of Practice. Trans. Richard Nice. Stanford University Press, 1990 (1980). Although not a Critical Theorist as such, Bourdieu's analysis of the logic of "practice theory" provides a similar account of professional agency.

Regelski, Thomas A. 2020. Tractate on critical theory and praxis: Implications for professionalizing music education. Action, Criticism, and Theory for Music Education 19 (1): 6-53. https://doi.org/ 10.22176/act19.1.6 
Carr, Wilfred and Stephen Kemmis. Becoming Critical: Education, Knowledge and Action Research. Falmer Press, 1986. Indispensable reading on Critical Theory applied to teaching.

Freire, Paulo. Education for Critical Consciousness. Continuum Publishers, 1996. An introduction to a parallel or related school of "critical education."

Fromm, Eric. The Fear of Freedom. ARK Paperbacks (London), 1984 (1942). A first generation Critical Theorist on the human tendency to submit to unfreedom.

Giroux, Henry A. Pedagogy and the Politics of Hope: Theory, Culture, and Schooling. Westview Press, 1997. A representative sample of articles on "critical education" in the tradition of the Frankfurt School.

Hoy, David Couzens and McCarthy, Thomas. Critical Theory. Blackwell, 1994. A useful introduction to Critical Theory.

Ingram, David. Critical Theory and Philosophy. Paragon House, 1990. An overview of Critical Theory.

Ingram, David. Habermas and the Dialectic of Reason. Yale University Press, 1987. A good introduction to Habermas.

Habermas, Jurgen. Legitimation Crisis. Beacon Press, 1975. A critique of scientist, technicist and institutional paradigms.

Habermas, Jurgen. Theory and Practice. Beacon Press, 1973. A "classical" critique of the scientistic ideology of objectivism and of Habermas' praxial theory of society.

Horkheimer, Max. Critical Theory: Selected Essays. Continuum Publishing, 1992. Essays representative of the seminal thinker in first generation Critical Theory.

Horkheimer, Max and Adorno, Theodor W. Dialectic of Enlightenment. Continuum Press, 1994. The "classical" critique of the problems stemming from the conflict between Enlightenment reason and empiricism-the "traditional theory" of which Critical Theory is critical.

Hubner, Kurt. Critique of Scientific Reason. Trans. P. R. Dixon, Jr., and H. M. Dixon. University of Chicago, 1983. A definitive critique of scientism by a leading contemporary Critical Theorist.

Listeon, Daniel P. and Zeichner, Kenneth M. Culture and Teaching. Lawrence Erlbaum, 1996. A summary of issues concerning "reflective teaching" (particular John Dewey, Donald Schőn and others).

Regelski, Thomas A. 2020. Tractate on critical theory and praxis: Implications for professionalizing music education. Action, Criticism, and Theory for Music Education 19 (1): 6-53. https://doi.org/ 10.22176/act19.1.6 
McCarthy, Thomas. The Critical Theory of Jurgen Habermas. MIT Press, 1994 (1978). A standard introduction to Habermas by a friend and critic of Habermas.

Pinar, William F., and William M. Reynolds, eds. Understanding Curriculum as Phenomenological and Deconstructed Text. Teachers College Press, 1992. A collection of "post-structuralist" papers on phenomenological bases of curriculum and action research.

Pusey, Michael. Jürgen Habermas. Tavistock Publications (London/NY), 1987. A concise outline of Habermas' thought and importance.

Regelski, Thomas A. "From modernity to post-modernism: Music as praxis." Philosophy of Music Education International Symposium III, UCLA, May 1997. Unpublished.

Regelski, Thomas A. "Action learning: Curriculum and instruction as and for praxis." Proceedings of the Charles Fowler Conference on Arts Education. University of Maryland, College Park, May 1997.

Regelski, Thomas A. "A critical pragmatism of creativity for general music." General Music Today, Vol. 10, No. 3 (Spring 1997).

Regelski, Thomas A. "A prolegomenon to a praxial theory of music and music education.” Finnish Journal of Music Education, Vol. 1, No. 1 (Fall 1996); reprinted in edited version in, Canadian Music Educator, Vol. 38, No. 3 (Spring 1997).

Regelski, Thomas A. "Critical Theory as a basis for critical thinking in music education." Proceedings: Critical Thinking in Music Education Symposium. University of Western Ontario, Canada, October 1996; reprinted Visions of Research in Music Education (January, 2005): http://rider.edu vrme/.

Regelski, Thomas A. "Taking the 'Art' of music for granted; A critical sociology of the aesthetic philosophy in music." Critical Reflections on Music Education, ed. L. R. Bartel and D. J. Elliott University of Toronto, Canadian Music Education Research Center, 1996.

Regelski, Thomas A. "Scientism in experimental research." Philosophy of Music Education Review, Vol. 4, No. 1 (Spring 1996).

Regelski, Thomas A. 2020. Tractate on critical theory and praxis: Implications for professionalizing music education. Action, Criticism, and Theory for Music Education 19 (1): 6-53. https://doi.org/ 10.22176/act19.1.6 
Regelski, Thomas A. "Sociology of knowledge, Critical Theory, and 'methodolatry' in music education." Interdisciplinary Conference in Music Education, Indiana University, Bloomington, April 1995.

Regelski, Thomas A. "Musicians, teachers, and the social construction of reality." Sociology of Music Education Conference, University of Oklahoma, April 1995.

Regelski, Thomas A. "Action research and critical theory: Empowering music teachers to professionalize praxis." Bulletin of the Council for Research in Music Education, No. 123 (Winter 1994-95).

Regelski, Thomas A. "A Critical Theory of culture and multiculturalism." Bordercrossings [interdisciplinary music studies] Conference. University of Ottawa, Canada, March 1995.

Regelski, Thomas A. "The action value of musical experience and learning." $A$ Compendium of Music Thought, 2 vols. John Paynter, ed. Routledge, 1993.

Regelski, Thomas A. "Action learning versus the Pied Piper approach.” Music Educators Journal, Vol. 69, No. 8 (April 1983).

Regelski, Thomas A. “Action learning." Music Educators Journal, Vol. 69, No. 6 (February 1983).

Rose, Andrea. "A reflective and critical internship in music education: Issues and possibilities." In, Clar Doyle, et al., Toward Building A Reflective and Critical Internship Program (The RCEP Model): Theory and Practice. Memorial University of Newfoundland, 1994.

Shor, Ira. Empowering Education: Critical Teaching for Social Change. University of Chicago Press, 1992. In the Paulo Friere tradition of "critical education"

Smith, Gary, ed. [Walter] Benjamin: Philosophy, Aesthetics, History. University of Chicago Press, 1989. A useful collection of writings by this first generation Critical Theorist.

Wartofsky, Max W. "Art as humanizing praxis." Models: Representations and the Scientific Understanding. Synthese Library: Studies in Epistemology, Logic, Methodology, and the Philosophy of Science, Vol. 129. Boston Studies in the Philosophy of Science, Vol. 48. Boston: D. Reidel, 1979.

Regelski, Thomas A. 2020. Tractate on critical theory and praxis: Implications for professionalizing music education. Action, Criticism, and Theory for Music Education 19 (1): 6-53. https://doi.org/ 10.22176/act19.1.6 
Wiggershaus, Rolf. The Frankfurt School: Its History, Theories, and Political Significance. Trans. M. Robertson. MIT Press, 1994. A comprehsive account of the Frankfurt School.

Regelski, Thomas A. 2020. Tractate on critical theory and praxis: Implications for professionalizing music education. Action, Criticism, and Theory for Music Education 19 (1): 6-53. https://doi.org/ 10.22176/act19.1.6 